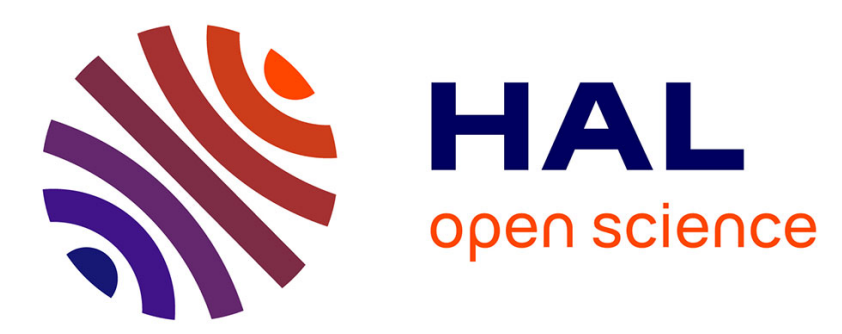

\title{
Economic Consequences of Union Dissolution in Italy: Findings from the European Community Household Panel
}

Fausta Ongaro, Stefano Mazzuco, Silvia Meggiolaro

\section{- To cite this version:}

Fausta Ongaro, Stefano Mazzuco, Silvia Meggiolaro. Economic Consequences of Union Dissolution in Italy: Findings from the European Community Household Panel. European Journal of Population / Revue européenne de Démographie, 2008, 25 (1), pp.45-65. 10.1007/s10680-008-9157-7 . hal00478419

\section{HAL Id: hal-00478419 \\ https://hal.science/hal-00478419}

Submitted on 30 Apr 2010

HAL is a multi-disciplinary open access archive for the deposit and dissemination of scientific research documents, whether they are published or not. The documents may come from teaching and research institutions in France or abroad, or from public or private research centers.
L'archive ouverte pluridisciplinaire HAL, est destinée au dépôt et à la diffusion de documents scientifiques de niveau recherche, publiés ou non, émanant des établissements d'enseignement et de recherche français ou étrangers, des laboratoires publics ou privés. 


\title{
Economic Consequences of Union Dissolution in Italy: Findings from the European Community Household Panel
}

\section{Les conséquences économiques des ruptures d'union en Italie: une exploitation du Panel Européen des Ménages}

\author{
Fausta Ongaro $\cdot$ Stefano Mazzuco $\cdot$ Silvia Meggiolaro
}

Received: 25 June 2007 / Accepted: 26 November 2007/Published online: 18 March 2008

(C) Springer Science+Business Media B.V. 2008

\begin{abstract}
Union dissolution is a constantly increasing phenomenon across Europe-even in Italy where the prevalence of divorce has always been among the lowest. This poses several questions on the potential consequences of such an event on the families involved. Many studies show that women usually experience the worst financial consequences, although there are few analyses on Italy, given the relatively low levels of union instability. In this work we study the impact of separation on the economic well-being of men and women using data from the European Community Household Panel (ECHP), analyzed using both objective and subjective measures. By means of a matching method, we also estimate the effect of union dissolution, taking account of possible variations according to the different living arrangements adopted by ex-partners after separation. Results confirm that women experience worse economic distress than men. However, there is also a significant drop in economic well-being among non-custodial fathers who live alone after separation. In addition, it is found that income-based measures do not encapsulate all the dimensions of well-being, and therefore need to be complemented with other measures.
\end{abstract}

Keywords Union dissolution · Italy $\cdot$ Economic well-being $\cdot$ ECHP

Résumé Les ruptures d'union sont en hausse constante en Europe-même en Italie où la fréquence des divorces est parmi les plus basses. Cette tendance soulève

\footnotetext{
F. Ongaro $\cdot$ S. Mazzuco $(\bowtie) \cdot$ S. Meggiolaro

Department of Statistical Sciences, University of Padova,

Via Cesare Battisti, 241, 35121 Padova, Italy

e-mail:mazzuco@stat.unipd.it

F. Ongaro

e-mail: ongaro@stat.unipd.it

S. Meggiolaro

e-mail: meg@stat.unipd.it
} 
différentes questions sur les conséquences des ruptures sur les familles concernées. De nombreuses études ont montré que c'étaient les femmes qui subissaient les conséquences financières les plus défavorables, mais la situation est mal connue en Italie, du fait de la rareté relative du phénomène. Nous analysons l'impact de la séparation sur le bien-être économique des hommes et des femmes à partir des données du Panel Européen des Ménages (ECHP), en nous appuyant à la fois sur des mesures objectives et subjectives. A l'aide d'appariements, les effets des ruptures d'unions sont estimés, en considérant une variation possible suivant le type de ménage dans lequel les anciens conjoints s'installent après la séparation. Les résultats confirment l'existence de plus grandes difficultés économiques chez les femmes. Toutefois, il y a également une chute significative de bien-être économique parmi les pères qui n'ont pas la garde des enfants et vivent seuls après la séparation. En outre, il apparaît que les mesures basées sur le revenu ne reflètent pas toutes les dimensions du bien-être, et doivent par conséquent être complétées par d'autres mesures.

Mots-clés Ruptures d'union · Italie · Bien-être économique · ECHP

\section{Introduction and Research Questions}

In recent years, a growing body of literature has emerged on the economic consequences of marital disruption. Some recent studies have explored this topic with a comparative approach (Dewilde 2003; Uunk 2004; Andreß et al. 2006; Aassve et al. 2007). Most of them use welfare regime theory (Esping-Andersen 1990) as a theoretical framework to explain differences across European countries: the weaker the support given by the state, the stronger the impact on couples of marital dissolution.

However, this equation is questionable, and country differences in the economic impacts of marriage dissolution may be explained in several ways: different characteristics of separating couples (for instance, in terms of educational level, see Harkonen and Dronkers 2006), different age profile and biographies before separation (the presence of children is an important variable, see Aassve et al. 2007) and different living arrangements after separation.

As a confirmation of this, other comparative analyses show that the Italian poverty rate among children living with only one parent (in most cases, the mother) is lower than in Germany or France, and similar to that of children living in intact families (Del Boca 2003). A convincing explanation attributes this result to country differences in the characteristics of divorced women. In this sense, single Italian mothers are more protected from poverty because of their higher human capital investment (education and work) and lower number of children (see again Del Boca 2003).

Another interesting point in such literature is the gender difference: empirical analysis has shown that women are in the weaker position, especially if they have children to look after (Douglas and Murch 2000; Jarvis and Jenkins 1999; McLanahan et al. 1995; Smock et al. 1999). 
Other analyses using individual data show that men do not suffer economically after separation; on the contrary, their household income even increases slightly (Andreß et al. 2006). However, the picture changes greatly when we consider the subgroup of parents. According to the estimates of Bradshaw and Mayhew (2002), in the case of non-custodial fathers at least, there is loss of income compared with their economic situation before separation, and in some cases the loss may even reach $50 \%$.

McManus and Di Prete (2001) and Aassve et al. (2007) show that men also lose economic status after their union dissolution. In particular, Aassve et al. (2007) find that although men are unaffected by union dissolution in monetary terms, when well-being is measured by non-monetary deprivation, the effect of separation becomes significant and in some cases even larger than that of women. However, this does not apply to Mediterranean countries, where the estimated impact of separation on non-monetary indices is not significantly different from zero.

This study focuses on a single country, namely Italy, rather than making further comparisons, in order to explore in more depth some of the mechanisms that welfare regime theory is not able to explain. In particular, we want to explore an important point: the economic consequences of separation are likely to vary across the different living conditions after union dissolution. Considering that in Italy maintaining a separate dwelling may be extremely expensive, we presume that those who, after separation, share their home with other adults (parents, new partners, friends) have a greater opportunity to make substantial savings in housing and housework costs with respect to those who choose (or are obliged) to live alone or with their children only. In this case, the family of origin, and especially parents, can provide substantial support to separated men and women, thus alleviating some of the negative effects of union dissolution.

If our hypothesis is confirmed, this provides an explanation for what Aassve et al. (2007) found (i.e. a negative effect for men when well-being is measured with nonmonetary indices, but not for men from Mediterranean countries): men in Southern Europe are more likely to return to the parental home, and parental support offsets the increased expenses due to separation, whereas men from Central and Northern Europe cannot count on this resource, and this is why they experience a worse economic situation after separation.

Moreover, two other technical issues are considered. The first one is the potential problem of selection bias. Some of the previously cited results were obtained with descriptive analyses, which compare circumstances before and after separation. Interpretation must be cautious in these cases. The trend observed in the changes of household income before and after separation may be the same as that of non-separating couples. Moreover, self-selection may severely bias the true causal relationship between union dissolution and economic consequences. Couples undergoing a marital split may be qualitatively different from those not doing so in terms of other background characteristics such as age, educational level, employment, income, living arrangements and social network prior to the event. These differences may affect both the risk of union dissolution and the economic well-being of partners, so that the real impact of the event may be biased. In order to 
tackle all these issues and to isolate the "pure" effect of the separation event, we use a Difference-in-Differences estimator combined with Propensity Score Matching techniques (see Rosenbaum and Rubin 1983; Heckman et al. 1997).

Second, we wished to apply several well-being measures. The economic consequences of a partnership dissolution are usually analyzed by examining changes in household income. However, even when net of taxes and adjusted for household composition, household income may give a distorted picture of the changes in individuals' economic well-being after separation. Marital dissolution implies important changes in daily expenditure and these changes differ greatly by gender. This feature is only partially taken into account by the household income measure. For example, in the case of dependent children, adjusted household income takes into account in some crude way the costs of children for the resident parent (usually the mother), but does not consider at all those of the non-resident parent (usually the father), such as increased expenses for alimony, travel to visit the children, or renting new accommodation. Using only household income to measure the economic consequences of union dissolution may therefore overestimate the economic well-being of the non-resident father after separation and, consequently, overestimate-at least for those with children-gender differences in the economic effect of separation.

Therefore, we did not use only the traditional monetary measure (equalized household income) in our analyses, but also other subjective indicators measuring the living standards and ability of households to afford a certain set of expenses. Our hypothesis is that subjective indicators may reveal negative consequences even though monetary ones do not.

The study is carried out using data from the eight waves of the European Community Household Panel (ECHP) carried out in 1994-2001. This source allows longitudinal analysis, so that we can observe short-term changes. In particular, we aim at analyzing changes in economic status from the year before the break-up to the year after it.

The work is organized as follows. Section 2 gives a brief description of the social and institutional Italian background. Section 3 describes the data and variables used. Sections 4 and 5 present the results: the former gives some descriptive results, and the latter illustrates the model (5.1) and the effects of union dissolution after controlling for selection bias (5.2) and the living arrangements after separation (5.3). Section 6 contains some concluding remarks.

\section{The Socio-institutional Background}

In Italy, the phenomenon of the civil dissolution of marriages has a short history. Until little more than 30 years ago, only legal separation was possible, with little impact on most of the civil effects of marriage. Divorce was introduced by law in 1970. A request for divorce could be made after 5 years of legal separation, and in 1987, a new law reduced this period from 5 to 3 years. According to Italian legislation therefore-with a few exceptions-legal separation is the necessary precondition for divorce. However, not all legal separations are converted into a 


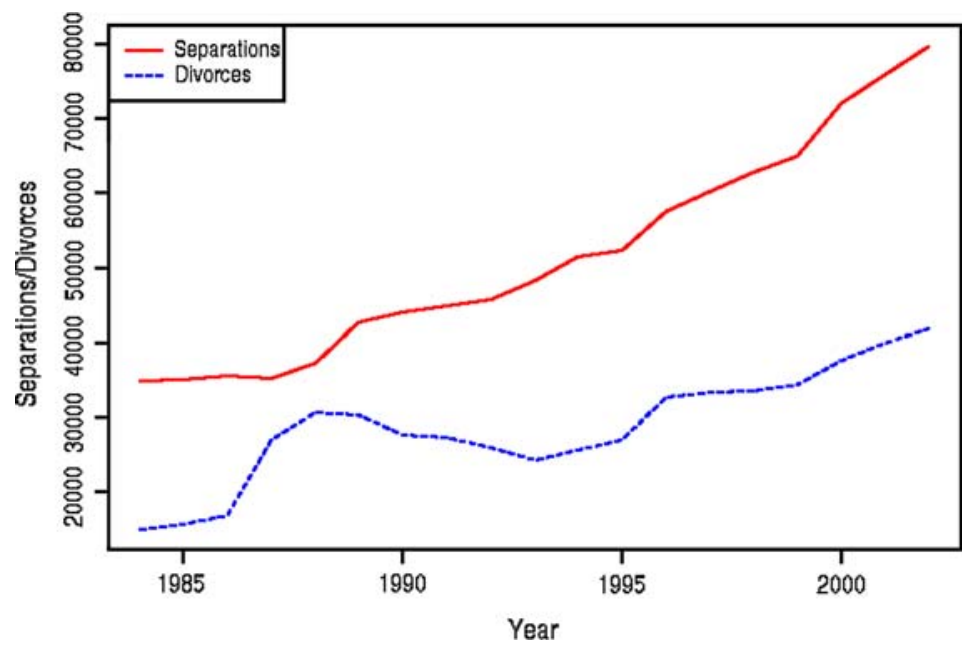

Fig. 1 Number of separations and divorces in Italy, 1984-2002. Source: National Statistical Institute (ISTAT)

divorce: only half $(51 \%)$ of the total number of separations granted in 1995 were translated later into divorce up to the year 2002 (ISTAT 2004).

It is not surprising, therefore, that dissolution of marital unions in Italy is much less frequent than in other European countries. The legislation has imposed (and still imposes) several constraints on divorce, and this indicates that its social acceptance is still relatively low.

However, in the last few years legal separations and divorces have increased sharply (Fig. 1). The total separation rate $(\times 1,000)$, which was 129 in 1990, 158 in 1995, 228 in 2000, reached 257 in 2002. A similar trend was observed for the total divorce rate: in the same years, its values $(\times 1,000)$ were, respectively, 78, 80, 115 and 131.

Legal separation and especially divorce are not generally events undergone by young people. The people who separated in 2002 were on average 40 years old (women 39, men 42) and their marriages had lasted on average 13 years. Most of these couples (69\%) had children and half $(52 \%)$ had at least one child under the age of 18 , custody of whom after separation was usually granted to the mothers. ${ }^{1}$ In addition, those who separated had higher human capital than intact couples: in 2002 , half ( $49 \%$ men, $53 \%$ women) had medium-high education and $70 \%$ of the women were employed (ISTAT 2004).

It is clear that this population of separated individuals is a selected population. The selection is connected to the fact that divorce is more common in some social groups (besides in some countries). We do not focus here on the literature on the causes of divorce, but we will nonetheless consider some remarks.

The economic tradition attributes the rise in divorce rates to changes in female socio-economic status due to their entry into the labour market. For Italy, this is

\footnotetext{
1 In 2002, after separation, in $85 \%$ of cases the custody of children under 18 was granted to mothers, in $4 \%$ to fathers and $11 \%$ to both parents.
} 
proved in the study by De Rose (1992). In fact, a particular trend, (considering female education and the risk of divorce) predicted by Goode $(1962,1993)$ and empirically tested by Harkonen and Dronkers (2006), is observed. They demonstrated an inverse relationship between the social composition of divorce and the level of modernization. In particular, this study found that in Italy, as well as in other countries where the dissolution rate is still low (France, Greece, Poland and Spain), higher educated couples divorce more often than lower educated couples. Conversely, when the dissolution level is high (Austria, Lithuania and the United States), lower educated couples divorce more often than higher educated ones.

These considerations indicate that caution is needed in interpreting analysis results and inter-country comparisons.

What kind of economic problems may these couples experience in the first years after separation, and what kind of support does Italian society offer them?

It is well-known that the Italian welfare system offers little support to individuals undergoing economic hardship, and family policies are also rather weak. At national level, most resources are channelled into social security, education and health. Both the education and public health systems offer public services (often of good quality) at relatively low cost; and for low-income families, costs may be further reduced or even cancelled. On the other hand, there are few specific services for working mothers (EUROSTAT 2007). Women can rely on a highly protective regulation of maternity leave, but beyond that, childcare services are deficient. Considering also the strict regulation of the labour market, and the rigid organization of everyday life, Italian women have serious difficulties in reconciling work and parenthood. Support from families (especially parents) often compensates for these deficiencies in the welfare system (Ministero del Lavoro e delle Politiche Sociali 2003). Cash support (to individuals and families) is also quite limited, and the few monetary allowances are mainly focused on reducing poverty (OECD 2004). Benefits for families with children are few and limited to low-income and large households. Moreover, the introduction of a minimum income is still at an experimental stage, with many variants, depending on the initiative of local administrations.

Therefore, in Italian society, separated men and women in economic difficulties can count on a system of public services and access to economic benefits which are means-tested. Access to these services (e.g. crèches, nursery schools) and benefits is further facilitated for single parent families.

However, for a separated woman, the main factor of economic security is participation on the labour market, considering that, generally, those who have jobs, have full-time permanent contracts. On the other hand, those without a personal income from work risk severe economic difficulties. With legal separation, solidarity ties do not disappear between the partners: the law obliges the economically stronger partner to pay maintenance to the weaker one. In practice, housewives cannot count too much on this tool, not only because her husband may not be able, or willing to pay the sums fixed by the judge ${ }^{2}$, but also because the courts have the tendency to assign only subsistence aims to this instrument. The

\footnotetext{
${ }^{2}$ In addition, Italian regulations do not provide fast inexpensive means of constraining reluctant partners to pay alimony (e. g. there are not forms of direct monetary transfer at source).
} 
statement according to which alimony is granted to a partner in case she/he has no "suitable personal income or cannot obtain it because of problems of age, health, or young children needing care" is interpreted in a very restrictive way and, in general, it is sufficient for a woman to have a job or to be in a position of getting one, for her not to receive alimony (Barbagli and Saraceno 1998). Judges' sentences do not consider that, in a still relatively rigid and employee-protective labour market like the Italian one, women who have invested in a family-particularly if they are relatively old and/or have very young children - not only have difficulty in finding adequately paid jobs, but even in finding any work at all. In short, considering the characteristics of both the labour market and welfare, we must conclude that Italian women who separate from their partners/husbands without being economically independent risk finding themselves in serious economic difficulties, and this may perhaps explain the relatively high rate of labour force participation among those who undergo a separation.

We should also consider housing market rigidities as an important factor. Finding somewhere to live after the break-up is a particularly hard problem for both expartners. In a country where house rents on the private market are extremely high, public residential building projects are relatively few, and the share of home owners is about $70 \%$ (ISTAT 2007), renting or purchasing a new home is very expensive. In this case, men with young children are the most disadvantaged. If there are dependent children, judges tend to assign the house in which the couple lived before separation to the custodial parent, independently of who the owner or tenant is. In $2002,58 \%$ of separation decisions assigned the house where the family lived before legal separation to the wife, and only in $23 \%$ of cases to the husband (the remaining cases are of couples who decided to leave their house to live in new, independent and different dwellings) (ISTAT 2004). This is consistent with the fact that women are the custodial parents ${ }^{3}$ much more frequently than men.

Substantial help is given to separated people by the family of origin. Although separation is still frowned upon in several sectors of society, siblings and especially parents are supportive to separated family members: they support them psychologically and help them face daily problems, offering goods, services, money and hospitality. The help offered by the family of origin is gender-differentiated because men and women have different needs: women mainly receive money, necessary goods, help in looking after children (allowing the mothers to work and maintain their economic independence); men mainly receive hospitality and help with their children (Barbagli and Saraceno 1998). As in other circumstances, the strong bonds of the Italian family make up for deficiencies in welfare, thus attenuating the negative economic consequences of union dissolution.

\footnotetext{
${ }^{3}$ Women do not always maintain their advantage. With divorce, things change, since $48 \%$ of couples leave their family house for separate, independent dwellings (ISTAT 2004). According to a 1990 survey (moreover, not representative of Italian reality) 2 years after separation, a woman with the custody of children maintains the use of a house only if it is the property of the woman herself, or of both partners; if the owner is the man or the man's parents, the use of the house generally returns to him (Barbagli and Saraceno 1998).
} 


\section{Data and Variables}

We use data from the ECHP to examine the relationship between union disruption and the subsequent economic situation. The ECHP is a longitudinal survey on private households, conducted annually between 1994 and 2001, in 15 EU countries (including Italy).

The survey collected detailed information on the economic and sociodemographic characteristics of households and of their members aged over 16. Its longitudinal design made it possible to follow up and interview the same set of people for several consecutive years.

For detailed analysis of the economic consequences of partnership dissolution, all eight waves of the panel (1994-2001) were examined. It was essential to use longitudinal data, as we aimed to compare the situation before and after separation. Thus for the population of interest, we considered information for years $t$ (before dissolution) and $t+1$ (after dissolution). We should bear in mind that with this small window of observation we measure only the short-term impact of separation. The limited time span of ECHP does not allow to identify medium- or long-term impact as longer time intervals would reduce the number of cases too sharply. Aassve et al. (2007) use the same window of observation. Uunk (2004) uses a larger window (2 years), but as a consequence the number of cases in Italy is only 69.

One technical issue was the definition of the event of interest. Accurate data exploration revealed that respondents have the tendency to confound actual and legal marital status. ${ }^{4}$ This, in practice, means that many "de facto" separated people do not report themselves as separated until their separation has been legally acknowledged. For example, we observe many individuals who stopped living with their partners without reporting being separated (about $26 \%$ of married men who reported being separated at time $t+1$ do not live in a couple at time $t$; the percentage is about $28 \%$ for women). So considering only marital status transitions created several inconsistencies with the living arrangements of separated individuals.

The alternative approach we take combines information on marital status and on partners' residence: if two partners stopped living in the same house (not because of the death of a partner-we excluded transitions to widowhood), they were deemed to be separated. Thus, a separation is defined as the end of cohabitation of partners, either in consensual union or in marriage. ${ }^{5}$

This choice clearly has some drawbacks: individuals who do not live together, not because of separation but for other causes, are considered to be separated (so that living apart together and commuting marriages may incorrectly be regarded as separations). However, we expect that such cases are rare. ${ }^{6}$ More important, in this

\footnotetext{
4 The categories available for marital status were: married, separated, divorced, widowed, never married.

5 For married couples this mainly corresponds to separation: we focus on separation and not divorce, because separation is connected to greater economic changes than legal divorce, which follows separation-sometimes several years later, when the economic situation may already have stabilized (see Andreß and Gullner 2001, quoted by Andreß et al. 2006).

${ }^{6}$ From another survey (Family and Social Subjects 2003) conducted by ISTAT, we find that the percentage of married individuals living outside the conjugal home is $2.7 \%$. Given the rarity of the phenomenon, the number of studies on this topic is negligible in Italy.
} 
way we defined the event of interest clearly and also identified the moment characterized by the greatest economic changes.

Analysis is restricted to the population less than 60 years old, to avoid confusing income changes due to separation and those due to retirement.

In this way, we identify 314 cases of partnership break-up, most of which (85\%) are marital dissolutions (Table 1). In particular, the sample of separated persons is made up of 142 men and 172 women: they come from 206 couples but only for 108 of them do we have information on both partners. There are some cases (64 for men and 34 for women), indeed, in which one of the two partners is not available after separation. Men are more likely to drop out after separation than women. This is reasonable given that men are also more likely to leave the conjugal home. Table 1 also shows some features of individuals undergoing a separation in the year $(t)$ before the event. They are individuals in their forties on average, with relatively long union durations (the mean duration of the marriage was about 13 years for men and 15 for women) and most of them have children (67\% of men and $75 \%$ of women). The deviation in duration of marriage and cohabitation for men and women is related to the attrition of separated individuals which is gender-specific. Separated women who drop out are younger on average (about 34 years old) than those who do not drop out (about 38 years old). Conversely, separated men who drop out are the same age on average as those who do not. This is probably an indirect effect of the way the conjugal home is assigned: women without childrenand therefore younger-are more likely to leave the home then mothers. This form of selection has to be borne in mind. As expected, female labour market participation is quite high (about 60\%), compared to national levels. Moreover, they are more represented in the North of Italy. Confirming the literature of Sect. 2, they have a quite high educational level.

The central focus of our analysis was the economic situation of individuals before and after separation.

ECHP provides rich information on individual (yearly) and household (monthly) incomes, together with data on many subjective aspects of the economic situation (such as housing quality, possession of durables, arrears and lifestyle quality).

Unfortunately, no other information related, for example, to home ownership and personal expenditure, is available.

ECHP provides two measures of total household income. The first one is the sum of household members' individual (yearly) net incomes and it is constructed from detailed questions on income from several sources, and reported retrospectively for the previous calendar year. The second measure is the household (monthly) net income and it refers to the current year; it is reported by the respondent to the household interview ${ }^{7}$ and not constructed from detailed information from different sources.

\footnotetext{
7 In the household interview, respondents are asked to recall all the sources of income (wages and salaries, income from self-employment or farming, pensions, unemployment/redundancy benefits, any other social benefits or grants and private income such as housing allowances) without specifying the amount of income from each source. Then the amount of household income is asked: "What is your household's total net income per month?".
} 
Table 1 Descriptive statistics of the sub-sample of separated individuals at the year t (before separation)

\begin{tabular}{lll}
\hline & Men & Women \\
\hline Number of union dissolutions (marital and non-marital) & 172 \\
Number of marital dissolutions & 120 & 147 \\
Average marriage duration & 12.9 & 14.6 \\
Average cohabitation duration & 4.5 & 5.5 \\
\% Couples with children & 66.9 & 75.0 \\
\% Living with parents & 8.5 & 4.7 \\
Mean age & 41.0 & 38.7 \\
Mean age of youngest child & 11.5 \\
\% Working & 10.5 & 59.3 \\
\% Working in self employment & 88.7 & 18.6 \\
\% With medium educational level & 38.9 & 8.1 \\
\% Living in the North & 18.3 & 45.3 \\
\% Living in the centre & 34.5 & 40.7 \\
\% Living in the South & 38.7 & 29.6 \\
Mean personal yearly income (in Euro) & 30.9 & 29.6 \\
Mean "rest of household" yearly equivalized income (in Euro) & 30.3 & 30.2
\end{tabular}

In theory, the first measure is more reliable than the second one, but in fact, there are some issues that make detailed yearly household income measure less attractive. First, it refers to year $t-1$ : this forces researchers to use its lagged value, thus reducing the sample size-and this is a particularly critical issue in our case given the already small number of cases we have. Second, being the summary of information collected from several questions, the detailed income measure is much more plagued by item non-response, whose prevalence is around $22 \%$, and unit non-response (around 3-4\%), and the imputation procedure implemented by Eurostat does not seem to fully overcome this problem (Nicoletti and Peracchi 2006).

Given these problems, we used the second measure of income for our analysis; in particular, we refer to the equivalized (according to the modified OECD scale) total monthly net household income 1 year before and one after separation, measured in euros, i.e. the sum of incomes from labour, assets, and private and public transfers, net of taxes, for all household members.

We also complement the income measure with several subjective items. Income is only a monetary measure of economic well-being, and considering the effect of separation on this aspect alone may be a limited approach, as other aspects of economic well-being (e. g. life-style and housing quality) are disregarded. On the one hand, the income measure is more reliable as it is more objective, and its change after separation is not affected by emotional distress, which could be the case when 
using subjective indicators. On the other hand, it is recognized that well-being has many more dimensions, often non monetary in nature (see, for instance, Atkinson 2003).

We, therefore, also considered some indicators measuring: perception of income variations compared to the previous year (on a five-point scale ranging from $1=$ clearly improved, to $5=$ clearly deteriorated), the ability to make ends meet (on a five-point scale ranging from $1=$ with great difficulty, to $5=$ very easily), the ability of the household to face a set of costs, related to home maintenance and to some payments. These items are reported as dichotomous variables with value of 1 if the household can afford a particular cost and 0 otherwise. Savings are also considered with a dummy variable, equal to 1 if there is normally some money left to save and 0 otherwise. Moreover a living standard index is obtained using some items related to life-style: they include the ability to pay for a week's annual holiday away from home, to buy new, rather than second-hand, clothes, to eat meat, chicken or fish, if desired, every second day and to have friends or family for drinks or meals at least once a month. Each item is described through a dummy variable equal to 1 if the household can afford that cost and 0 otherwise; the living standard index is obtained as the arithmetic mean of these items. A measure of its psychometric quality is provided by Cronbach's Alpha which, with a value of 0.8 , assures the consistency of this index (Nunally 1978).

In addition, labour market transitions are analyzed, expecting that individuals, usually women without jobs, are looking for a source of personal income after separation. From Table 1 we note that the percentage of working women is about $60 \%$ (about $90 \%$ for men), and women's income is lower on average than men's and $18 \%$ do not have any income at all. These descriptive figures suggest that prevalence of the male-breadwinner model among Italian families is still high. As a consequence, some women probably need a new source of income after separation, so they may look for a job.

Finally, we considered transitions in living arrangements of men and women who underwent a separation (Table 2).

The definition of living arrangements used here distinguishes couples with other adults (parents or siblings, excluding adult children) from couples without other adults. Most separated individuals ( $83 \%$ of men, $85 \%$ of women) had lived with their families without other adults before separation. The majority of them had children. After separation there is a dramatic change in the ex-partners' living arrangements, and the change depends strongly on the presence of children. When there are no children, the routes taken by men and women after separation are quite similar: most of them live alone whereas about $17 \%$ return to the parental home. There is a greater gender difference among couples with children: $23 \%$ of separated men move to a single-parent family after separation, but the figure for women reaches $85 \%$. As a consequence, after separation, on the whole, only $15 \%$ of men live as single-parents, $26 \%$ return to the parental home, and the majority live alone. $60 \%$ of women live with their children (as single parents), $25 \%$ live alone and fewer than $10 \%$ return to their parents. In both cases (especially for men), fewer than $5 \%$ form new couples. 
Table 2 Living arrangement transitions of individuals who underwent a separation

\begin{tabular}{|c|c|c|c|c|c|}
\hline \multirow{2}{*}{$\begin{array}{l}\text { After separation } \\
\text { (time } t+1) \\
\text { Before separation } \\
\text { (time } t \text { ) }\end{array}$} & \multicolumn{2}{|c|}{ Without others } & \multicolumn{2}{|c|}{ With others (with or without children) } & \multirow{2}{*}{$\begin{array}{l}\text { Number of } \\
\text { cases }(=100)\end{array}$} \\
\hline & Alone & With children & With a new partner & With parents & \\
\hline \multicolumn{6}{|l|}{ Men } \\
\hline \multicolumn{6}{|l|}{ Without others } \\
\hline Couple & 81.08 & 2.70 & 0.00 & 16.22 & 37 \\
\hline Couple with children & 51.85 & 23.46 & 1.23 & 23.46 & 81 \\
\hline \multicolumn{6}{|l|}{ With others } \\
\hline Couple & 40.00 & 10.00 & 0.00 & 50.00 & 10 \\
\hline Couple with children & 21.43 & 7.14 & 21.43 & 50.00 & 14 \\
\hline Total & 55.63 & 15.49 & 2.82 & 26.06 & 142 \\
\hline \multicolumn{6}{|l|}{ Women } \\
\hline \multicolumn{6}{|l|}{ Without others } \\
\hline Couple & 71.43 & 5.71 & 5.71 & 17.14 & 35 \\
\hline Couple with children & 12.61 & 85.59 & 0.90 & 0.90 & 111 \\
\hline \multicolumn{6}{|l|}{ With others } \\
\hline Couple & 37.50 & 0.00 & 37.50 & 25.00 & 8 \\
\hline Couple with children & 5.56 & 38.89 & 22.22 & 33.33 & 18 \\
\hline Total & 25.00 & 60.47 & 5.81 & 8.72 & 172 \\
\hline
\end{tabular}

\section{Descriptive Results}

A preliminary descriptive analysis, based on the eight waves of the ECHP, suggests that the economic consequences of separation are gender-specific, as also found in the literature. Table 3 shows descriptive statistics of the well-being indicators we considered for separated individuals before and after the event.

Starting from the objective measure of well-being, we see an income drop after separation for women, whereas men's average income increases by more than $25 \%$. However, this is not entirely consistent with the subjective perception of income situation compared to the previous year: for women the percentage of those reporting a deteriorated income situation grows from 31 to $55 \%$, but this happens also for men, although to a lesser extent (from 36 to 46\%). The percentages of those reporting difficulties in making ends meet increase for women after separation and slightly decrease for men. In addition, women have more difficulties after separation in affording several home-related costs (e.g. heating and furniture) and some payments (scheduled rent), whereas the figures for men do not vary significantly after separation. The ability to afford certain basic expenses also decreases for women. For instance, before separation $43 \%$ reported being able to replace wornout furniture, and this fraction drops to $34 \%$ after separation. These figures remain practically unaltered for men. The percentage of those who are left with some money for savings also decreases, and again the drop is much larger for women. 
Table 3 Household economic conditions of individuals who underwent a separation, 1 year before and 1 year after the event

\begin{tabular}{|c|c|c|c|c|}
\hline & \multicolumn{2}{|c|}{ Male } & \multicolumn{2}{|c|}{ Female } \\
\hline & Before & After & Before & After \\
\hline Total monthly net household income (equivalized, in Euro) & 924 & 1,175 & 839 & 719 \\
\hline $\begin{array}{l}\text { Household reporting a deteriorated income situation compared } \\
\text { with previous year }(\%)\end{array}$ & 36.3 & 45.8 & 30.8 & 54.6 \\
\hline Household reporting difficulties making ends meet $(\%)$ & 55.6 & 52.1 & 61.1 & 71.5 \\
\hline Household can afford to keep its home adequately warm (\%) & 83.1 & 82.4 & 82.5 & 78.4 \\
\hline Household can afford to replace any worn-out furniture (\%) & 45.8 & 42.3 & 42.7 & 33.9 \\
\hline Household has been unable to afford payments related to life-style ${ }^{a}$ & 0.69 & 0.75 & 0.78 & 0.89 \\
\hline $\begin{array}{l}\text { Household has been unable to pay scheduled rent for } \\
\text { accommodation }(\%)\end{array}$ & 2.8 & 3.5 & 2.3 & 3.5 \\
\hline Household has been unable to pay scheduled mortgage payments $(\%)$ & 1.4 & 0.0 & 1.7 & 0.0 \\
\hline $\begin{array}{l}\text { Household has been unable to pay scheduled utility bills (electricity, } \\
\text { water, gas) (\%) }\end{array}$ & 7.7 & 5.6 & 8.2 & 8.1 \\
\hline $\begin{array}{l}\text { Household has been unable to pay hire-purchase instalments or other } \\
\text { loan repayments }(\%)\end{array}$ & 4.9 & 1.4 & 4.7 & 2.9 \\
\hline Household has some money left for savings (\%) & 31.7 & 28.6 & 32.6 & 19.8 \\
\hline Working $(\%)$ & 88.7 & 86.6 & 59.3 & 62.9 \\
\hline
\end{tabular}

${ }^{a}$ Arithmetic mean values of several life-style related items

Finally, we note that women's labour market participation rate increases after separation.

\section{Modelling the Economic Consequences of Union Dissolution}

\subsection{Causal Analysis}

Although the above descriptive analysis offers many indications on the association between separation and the subsequent changes in life-style, it does not suffice to identify the causal relation between the two processes. Differences between those who undergo separation and those who do not may be influenced by the different background characteristics of the two groups. For instance, we may expect that couples undergoing separation have a different level of well-being prior to separation with respect to that of other couples. Generally speaking, the two groups may be qualitatively different in terms of many background variables, and we need to control for these variables if we aim to tease out the causal effect of separation from the spurious dependence brought about by these variables.

More than one solution is possible for this identification of causal effect. One is to use an instrumental variable (Angrist 1998), which allows us to simulate a random assignment of treatment (in our case, the treatment is the point of separation). In observational studies, treatment is not randomly assigned, but there may be an exogenous variable correlated with treatment. For example, Angrist and Evans 
(1998) used same-sex children as an instrument to estimate the effect of fertility on parents' labour supply. However, finding such a variable is extremely difficult, as highlighted by Heckman et al. (1999).

A different route was proposed by Rosenbaum and Rubin (1983) by assuming that we record all variables $X$ that confound the effect of treatment on outcome. This may be identified by making the estimate conditional on $X$. A dimensionality problem arises when the number of possible confounder variables is higher than 5 , but the above authors showed that it is possible to condition on the propensity score, instead of $X$, i.e. the probability of undergoing the event conditional on the value of $X$, easily estimated by means of a probit or logit regression model.

Given the relative richness of information of the ECHP data and the problems of finding a proper instrumental variable, we use propensity score matching to isolate the causal effect of separation. Therefore, we assume that we observe all the confounding variables in our dataset-an assumption commonly referred to as the conditional independence assumption (CIA), ruling out the effect of unobserved heterogeneity. However, CIA is quite unlikely to hold, as there may be some confounding variables that are not in the set of observed covariates. These variables induce a hidden bias in the propensity score matching estimates. Heckman et al. (1997) suggest relaxing CIA, combining a Difference-in-Differences estimator with the matching procedure. Basically, we estimate the effect of treatment on the prime difference of outcome in two subsequent years. Thus, for treated individuals we have the difference between outcome 1 year after treatment and 1 year before, whereas for controls (i.e., non-treated individuals), we only have just the difference between two consecutive years. In practice, this is a fixed-effect estimator, and if unobserved heterogeneity is time-invariant, its effect is netted out by the Differencein-Differences estimator. This means that a milder assumption than CIA is imposed on our inference framework.

As explained in Sect. 3, most of the men and women in our sample are members of the same married couple, hence they have the same value of household income. This means that the well-being measures at $t$ are equal between members of the same couple. The results may be affected by this sort of dependency, but as we use separate models for men and women, comparisons can be made.

There are many matching methods (see Becker and Ichino 2002; Smith and Todd 2005 , for a list). In this article, we use a nearest-neighbour method in which every treated individual is matched to the closest control, closeness being determined by the distance of the propensity scores.

Table 4 shows the results of the logit model used to estimate the propensity scores. We included here wave, age, gender, regional location, education, employment status, type of union, number of children, whether the individual was living with parent or not before separation and yearly personal and household income, the latter being constructed by subtracting the yearly personal income of the individual from the total yearly household income, and then equivalized. We also included the value of outcome before treatment: as we estimate the impact of separation on several outcomes, specification of the logit model changes accordingly.

The results of our logit model are in line with the literature referring to Italy and some other countries (Harkonen and Dronkers 2006). The propensity to separate 
Table 4 Logit model on probability of undergoing separation (estimates for propensity score)

\begin{tabular}{|c|c|c|c|c|}
\hline & \multicolumn{2}{|c|}{ Men } & \multicolumn{2}{|c|}{ Women } \\
\hline & Estimate & SE & Estimate & SE \\
\hline Intercept & -6.671 & $1.384 * * *$ & -4.620 & $1.329 * * *$ \\
\hline Year 1995 (Ref. 1994) & 0.459 & 0.350 & 0.233 & 0.309 \\
\hline Year 1996 (Ref. 1994) & 0.698 & $0.338 * *$ & 0.401 & 0.303 \\
\hline Year 1997 (Ref. 1994) & 0.741 & $0.339 * *$ & 0.692 & $0.292 * *$ \\
\hline Year 1998 (Ref. 1994) & 0.263 & 0.371 & 0.343 & 0.312 \\
\hline Year 1999 (Ref. 1994) & 0.115 & 0.386 & 0.113 & 0.331 \\
\hline Year 2000 (Ref. 1994) & 0.245 & 0.387 & -0.002 & 0.350 \\
\hline Cohabiting union (Ref. Marriage) & 1.964 & $0.253 * * *$ & 1.966 & $0.235 * * *$ \\
\hline Age & -0.015 & 0.010 & -0.020 & $0.009 * *$ \\
\hline Education: medium (Ref. low) & 0.146 & 0.198 & 0.289 & 0.177 \\
\hline Education: high (Ref. low) & 0.948 & $0.255 * * *$ & 0.091 & 0.309 \\
\hline $\begin{array}{l}\text { In paid employment (Ref. not } \\
\text { working) }\end{array}$ & -0.031 & 0.308 & 0.192 & 0.246 \\
\hline Self employed (Ref. not working) & 0.316 & 0.304 & 0.196 & 0.287 \\
\hline Personal income (log) & -0.094 & $0.034 * * *$ & 0.044 & $0.026^{*}$ \\
\hline "Rest of household" income (log) & 0.310 & 0.189 & -0.080 & 0.183 \\
\hline North (Ref. South) & 0.125 & 0.225 & 0.209 & 0.206 \\
\hline Centre (Ref. South) & 0.413 & $0.226^{*}$ & 0.388 & $0.209 *$ \\
\hline Number of children & -0.278 & $0.099 * * *$ & -0.033 & 0.085 \\
\hline Parents living with household & 0.428 & $0.194 * *$ & 0.400 & 0.252 \\
\hline
\end{tabular}

Significance levels: ***, $0.01 ; * *, 0.05 ; *, 0.1$

decreases with age, but its effect is significant only for men. Cohabiting unions are more prone to dissolution, and a high educational level is also positively associated with this risk. Again, this effect is significant only for men. Interestingly, personal income has a different impact according to gender: for men the higher the income, the lower the propensity to separate, while for women the opposite is true. Having children has a protective function against separation although this is only evident for men. People living in the south of Italy are less likely to separate. Lastly, if men live with their parents, the probability of union dissolution increases.

Therefore, the following estimates were computed net of these variables. Note that, in this framework, the correct specification of the logit model is not a problem: this method is basically a non-parametric one, so we do not need to specify the correct functional form of the relation between treatment and covariates (see Caliendo and Kopeinig 2005).

\subsection{Results}

The results of the matching method outlined above are reported in Table 5. The quality of matching has been assessed using a $t$-test for the equality of means of the treated and control groups for each covariate. The test shows that after matching, 
Table 5 Effects of separation on several outcomes

\begin{tabular}{|c|c|c|c|c|c|c|}
\hline & \multicolumn{3}{|c|}{ Men } & \multicolumn{3}{|c|}{ Women } \\
\hline & Effect & SE & $N$ & Effect & SE & $N$ \\
\hline Total monthly net household income (Euro) & 234 & $171.5^{* * * *}$ & 142 & -190 & $110.7 * * *$ & 172 \\
\hline Income situation compared with previous year & -0.155 & 0.132 & 142 & -0.413 & $0.126^{* * * *}$ & 172 \\
\hline Ability to make ends meet & -0.113 & 0.146 & 142 & -0.430 & $0.131 * * *$ & 172 \\
\hline Ability to afford payments related to life-style & -0.155 & 0.132 & 142 & -0.036 & 0.117 & 170 \\
\hline Ability to keep home adequately warm & -0.063 & 0.048 & 142 & -0.018 & 0.045 & 170 \\
\hline Inability to pay scheduled rent & -0.021 & 0.024 & 141 & -0.023 & 0.023 & 171 \\
\hline Inability to pay scheduled mortgage payments & 0.014 & 0.017 & 142 & -0.012 & 0.016 & 171 \\
\hline Inability to pay scheduled utility bills & -0.007 & 0.036 & 142 & -0.029 & 0.035 & 171 \\
\hline Inability to pay loan repayments & 0.007 & 0.029 & 142 & 0.000 & 0.027 & 171 \\
\hline Some money left for savings & 0.029 & 0.065 & 140 & -0.145 & $0.060 * *$ & 172 \\
\hline Exit from the labour market (workers only) & 0.008 & 0.031 & 126 & -0.039 & 0.046 & 102 \\
\hline $\begin{array}{l}\text { Entry into the labour market } \\
\text { (inactive persons only) }\end{array}$ & 0.063 & 0.204 & 16 & 0.114 & $0.067 *$ & 70 \\
\hline Weekly working hours (workers only) & 0.588 & 1.260 & 114 & 1.926 & 1.196 & 94 \\
\hline
\end{tabular}

Significance levels: ***, $0.01 ; * *, 0.05 ; *, 0.1$

Estimates with propensity score matching (1 neighbour, 1,000 replications)

the two groups are balanced, i.e. they do not show any significant difference in terms of observed covariates.

Two aspects of the results of Table 5 must be borne in mind: first, we transformed some well-being indicators in order to harmonize them: for each item a negative sign means a well-being reduction and a positive sign a well-being increase. This does not apply to labour force outcomes, whose values in Table 5 reflect the effect on labour force exit rate, labour force entry rate and number of hours worked, respectively. Second, the results of Table 5 must be interpreted bearing in mind the Difference-in-Differences estimator. This means that the table shows the difference between the average changes in the outcome of treated groups and in the outcome of control groups. For example, the estimate -190 for women's total monthly household income means that the difference between income before and after separation is lower by 190 euro on an average than the average income change of controls. Bearing this in mind, the results basically confirm the findings of descriptive analysis: the income situation of women is highly likely to worsen after separation, more so than that of men. The latter may even be better off after separation, as their equivalent monthly household income is significantly higher, whereas women's income drop significantly after separation.

This is confirmed by the subjective perception of economic status: for women, there is a significant drop in the ability to make ends meet due to separation, and they report a worsened income situation compared with the previous year; conversely men's changes are not significant. Another significant effect is found on savings: the DID effect of women is -0.145 , while the figure for men is not significantly different from zero. The effect of separation on transitions in the labour 
market is also interesting, since we found that women out of the labour market are more likely to enter the labour force after separation. This result can be interpreted as a signal that women undergo a significant well-being reduction after union dissolution, a deterioration they try to cope with by finding a new job.

\subsection{Influence of Living Arrangements after Union Dissolution}

In the next step, we study in more detail the economic effects of union dissolution. Table 2 shows that men, especially if they have children, are more likely to return to their parental home after union dissolution, a fact that may partly explain the low economic impact of separation on them. The presence of children greatly influences home assignment within the couple: mothers are highly likely to remain in the same home after conjugal separation, and fathers are highly likely to leave. This may be an advantage for women in terms of housing quality but a disadvantage in terms of income, as they need to share income with other non-productive family members. Conversely, men are likely to be forced to leave the conjugal home and find new accommodation, and the increased expense for the new dwelling may offset economic advantages in terms of income (unless they return to their parental home). So we examined the economic effect of separation depending on the living arrangements after the union dissolution. We know that the choice of living arrangement may be endogenous with the effect of union dissolution on economic well-being. For instance, it may be argued that choice of living arrangements after separation is, at least partially, driven by the economic situation. However, we may reasonably assume, on the basis of the relatively high social acceptance of coresidence with parents, even when over 30, that choice of living arrangements in Italy is actually driven by the possibility of moving to the parental home: if men can go back to their parents, they will probably do so, regardless of their economic situation, thus avoiding a difficult search for a new dwelling. If they cannot, then they have little choice, as alternatives to moving into a single-person household after union dissolution are rare in Italy. Women with children are forced to remain in the conjugal home they are assigned, if they want to keep it. So they are very unlikely to move to their parental home, regardless of their economic situation. On the basis of these arguments, we are confident that living arrangements after union dissolution are not closely linked to the economic well-being of spouses, at least in the period immediately after separation.

We replicated the above analysis on the subgroup of individuals with children, and estimated the impact of union dissolution combined with subsequent living arrangements. We considered a specific subgroup of parents. For men "treatment" consists of undergoing a separation and subsequently living alone, for women we define "treatment" as undergoing separation and becoming a single parent the following year. In this way, we identify what we expect to be the most common living arrangements adopted by fathers and mothers after separation. Non-custodial fathers are also usually obliged to leave the conjugal home, which is assigned to custodial mothers, and to pay alimony for their children, so this probably is also the subgroup of men who experience the most difficult economic situation. Similarly, 
Table 6 Effects of separation on several outcomes for two specific subgroups of separated persons. Estimates with propensity score matching (1 neighbour, 500 replications)

\begin{tabular}{|c|c|c|c|c|c|c|}
\hline & \multicolumn{3}{|c|}{$\begin{array}{l}\text { Non-custodial fathers } \\
\text { living alone }\end{array}$} & \multicolumn{3}{|c|}{ Lone mothers } \\
\hline & Effect & SE & $N$ & Effect & SE & $N$ \\
\hline Total monthly net household income (Euro) & 598 & $415.1 * * *$ & 45 & -164 & $166.9^{*}$ & 102 \\
\hline Income situation compared to last year & -0.441 & $0.170 * *$ & 45 & -0.530 & $0.127 * * *$ & 102 \\
\hline Ability to make ends meet & -0.089 & 0.263 & 45 & -0.451 & $0.172 * *$ & 102 \\
\hline Ability to afford payments related to life-style & -0.467 & $0.235^{*}$ & 45 & -0.337 & $0.156 * *$ & 101 \\
\hline Ability to keep home adequately warm & -0.057 & 0.056 & 45 & -0.085 & $0.046 *$ & 102 \\
\hline Inability to pay scheduled rent & 0.044 & 0.045 & 45 & 0.039 & 0.030 & 102 \\
\hline Inability to pay scheduled mortgage payments & -0.022 & 0.018 & 45 & -0.010 & 0.022 & 102 \\
\hline Inability to pay scheduled utility bills & -0.060 & $0.030 * *$ & 45 & -0.046 & 0.033 & 102 \\
\hline Inability to pay loan repayment & -0.044 & 0.058 & 45 & -0.020 & 0.033 & 102 \\
\hline Some money left for savings & -0.106 & 0.082 & 44 & -0.161 & $0.054 * * *$ & 102 \\
\hline Exit from the job market (workers only) & 0.004 & 0.025 & 38 & 0.012 & 0.039 & 57 \\
\hline Entry in the job market (inactive persons only) & - & - & - & 0.100 & $0.053^{*}$ & 45 \\
\hline
\end{tabular}

Significance levels: $* * *, 0.01 ; * *, 0.05 ; *, 0.1$

custodial mothers are also likely to experience the worst-case scenario among separated women as they must share their income with their children, and the alimony they receive rarely offsets the increased expenses. If the above arguments are true, estimations of the effects of marital dissolution on these particular subgroups should reflect this. We expect to find a negative and significant effect even for men, with women showing an even higher impact of separation than that reported in Table 5.

The estimates shown in Table 6 basically meet our expectations: despite their increased income, separated men's perception is that their well-being has dropped after their union dissolution. They report a significantly more deteriorated income situation than the control group. The effect on ability to pay utility bills is -0.060 , i.e. their ability to pay utility bills decreases. The life-style conditions index is also significantly lower. The situation of separated women further deteriorates when we consider lone mothers only. The (negative) effect on income is largely confirmed by the subjective perception. We find a significant effect on the ability to make ends meet $(-0.530)$, to afford payments related to life-style $(-0.337)$, to keep the house adequately warm $(-0.085)$ and to save money during the year $(-0.161)$. In addition, we still find an effect on labour market entry rate-separated women being more likely to enter the job market than the control group. Therefore, excluding men returning to their parents' home after separation, we find a significant impact of union dissolution on men's well-being, or at least on their subjective perception of the quality of their life-style. As a confirmation of this, the same analysis was conducted for fathers and mothers returning to the parental home. But the very small number of cases (37 for men, 15 for women) does not allow us to draw any inference from it. 


\section{Conclusions}

The aim of this work was to provide an initial comprehensive, robust assessment of the economic impact of union dissolution in Italy, considering that until nowpartly because of its low frequency-few empirical data were available to study the phenomenon.

Our analyses, carried out on data representative at a national level and using methods that take into account possible disturbing factors, indicate that union dissolution in Italy produces differentiated economic effects for men and women, at least in the short term.

Even after controlling for several conditions preceding separation, we found that women are in a weaker position than men. Monetary and subjective measures of economic well-being both indicate a worsening of women's status in the year after separation with respect to the last year of union. This happens even though union dissolution forced some of them to increase their personal income by taking a job after the event. Single mothers, in particular, suffer the heaviest drop in living standards. Separation has mixed effects among men, suggesting that here the event may produce different economic consequences according to the subsequent living conditions. In general, men do not undergo negative economic consequences after separation but when our analysis is concentrated on noncustodial fathers living alone, we find that they also experience a drop in their standard of living, even though their household income increases. The scarcity of cases does not allow deeper analyses on this point (models for all subgroups of separated men and women, classified according to the different living arrangements after separation, could not be run). Our results empirically support the hypothesis that the better economic position of Italian men depends on two factors: personal income, and the opportunity, provided by the strong family network, of returning — at least in the first period after separation - to the parental home.

Two other important and more general results of this study must be stressed.

First, household income, even when equivalized and net of taxes, must be used with caution as a proxy of changes in economic well-being for separated people. The present empirical analysis demonstrates that individuals may suffer statistically significant economic penalties in their living standards, even with a significant increase in equivalized household income.

Second, separation may have opposite economic consequences in different subgroups of separated people, and this does not depend only on the conditions preceding separation, but also on those subsequent to the event. Considering that, at least for those who are parents, post-separation living arrangements are genderdifferentiated, this work indicates that a correct interpretation of the gender differences in the economic impact of union dissolution should take into account the living arrangements after separation of both men and women. The same result also suggests caution in interpreting the effects of union dissolution across different countries. Indeed, results may be influenced by country differences in the distribution of living arrangements after separation. 


\section{References}

Aassve, A., Betti, G., Mazzuco, S., \& Mencarini L. (2007). Marital disruption and economic well-being: A comparative analysis. Journal of the Royal Statistical Society, Series A, 170(3), 781-799.

Andreß, H. J., Borgloh, B., Broeckel, M., Giesselmann, M., \& Hummelsheim D. (2006). The economic consequences of partnership dissolution. A comparative analysis of panel studies from Belgium, Great Britain, Italy and Sweden, European Sociological Review, 22(5), 533-560.

Andreß, H. J., \& Gullner, M. (2001). Scheidung als armutsrisiko. In E. Barlosius \& W. LudwingMayerhofer (Eds.), Die Armut der Gesellschaft (pp. 169-197). Opladen: Leske + Budrich.

Angrist, J. (1998). Estimating the labor market impact of voluntary military service using social security data on military applicants. Econometrica, 66(2), 249-288.

Angrist, J., \& Evans, W. E. (1998). Children and their parents? Labor supply: Evidence from exogenous variation in family size. American Economic Review, 88, 450-477.

Atkinson, A. B. (2003). Multidimensional deprivation: Contrasting social welfare and counting approaches. Journal of Economic Inequality, 1, 51-65.

Barbagli, M., \& Saraceno, C. (1998). Separarsi in Italia. Bologna: Il Mulino.

Becker, S. \& Ichino, A. (2002). Estimation of average treatment effects based on propensity scores. The STATA Journal, 2 (4), from http://www.stata-journal.com/abstracts/st0026.pdf.

Bradshaw, J., \& Mayhew, E. (2002). The treatment of the children of divorced parents with care by the tax and benefit system in 22 countries. In Seminar on Children and Divorce, Institut d'Infancia $i$ Mon Urba, Barcelona, 19-20 September 2002.

Caliendo, M., \& Kopeinig, S. (2005). Some practical guidance for the implementation of propensity score matching. IZA DP no. 1588. Bonn: IZA.

Del Boca, D. (2003). Mothers, fathers, and children after divorce: The role of institutions. Journal of Population Economics, 16(3), 399-422.

De Rose, A. (1992). Socio-economic factors and family size as determinants of marital dissolution in Italy. European Sociological Review, 8(1), 71-91.

Dewilde, C. (2003). The financial consequences of relationship dissolution for women in western Europe. In E. Ruspini \& A. Dale (Eds.), The gender dimension of social change: The contribution of dynamic research to the study of women's life courses (pp. 81-110). Bristol: The Policy Press.

Douglas, G., \& Murch, M. (2000). How parents cope financially on marriage breakdown, Joseph Rowntree Foundation, from http://www.jrf.org.uk/knowledge/findings/socialpolicy/480.asp.

Esping-Andersen, G. (1990). The three worlds of welfare capitalism. Cambridge: Polity Press.

EUROSTAT (2007). Labour market policy. Eurostat Statistical Books, Luxembourg: Office for Official Publications of the European Communities.

Goode, W. J. (1962). Marital satisfaction and instability. A cross-cultural class analysis of divorce rates. In R. Bendix \& S. M. Lipset (Eds.), Class, status, and power. Social stratification in comparative perspective (pp. 377-387). New York: The Free Press.

Goode, W. J. (1993). World changes in divorce patterns. New Haven: Yale University Press.

Harkonen, J., \& Dronkers, J. (2006). Stability and change in the educational gradient of divorce. A comparison of seventeen countries. European Sociological Review, 22(5), 501-517.

Heckman, J. J., Ichimura, H., \& Todd, P. E. (1997). Matching as an econometric evaluation estimator: Evidence from evaluating a job training programme. Review of Economic Studies, 64, 605-654.

Heckman, J. J., LaLonde, R. J., \& Smith, J. A. (1999). The economics and econometrics of active labor market programs. In O. Ashenfelter \& D. Card (Eds.), Handbook of labor economics (pp. 1865-2097). Amsterdam: Elseviere Science.

ISTAT. (2004). Separazioni, divorzi e affidamento dei minori, anno 2002, Centro di Informazione Statistica - Servizio Giustizia, Roma: ISTAT.

ISTAT. (2007). La vita quotidiana nel 2006, Informazioni - 12, Roma: ISTAT.

Jarvis, S., \& Jenkins, S. P. (1999). Marital splits and income changes: Evidence from the British Household Panel Survey. Population Studies, 53(2), 237-254.

McLanahan, S. S., Casper, L. M., \& Soresen A. (1995), Women's role and women's poverty. In K. O. Mason \& A. M. Jensen (Eds.), Gender and family change in industrialized countries (pp. 258-278). Oxford, UK: Clarendon Press.

McManus, P. A., \& Di Prete, T. A. (2001) Losers and winners: The financial consequences of separation and divorce for men. American Sociological Review, 66(2), 246-268. 
Ministero del Lavoro e delle Politiche Sociali. (2003). Libro Bianco sul Welfare. Proposte per una società dinamica e solidale, Roma.

Nicoletti, C., \& Peracchi, F. (2006). The effects of income imputation on microanalyses: Evidence from the European Community household panel. Journal of the Royal Statistical Society, Series A, 169(3), 625-646.

Nunally, J. V. (1978). Psychometric theory. New York: McGraw-Hill.

OECD. (2004). OECD employment outlook. Paris: Oecd.

Rosenbaum, P. T., \& Rubin, D. B. (1983). The central role of the propensity score in observational studies for causal effects. Biometrika, 70(1), 41-55.

Smith, J. A., \& Todd, P. (2005). Does matching overcome Lalonde's critique of nonexperimental estimators? Journal of Econometrics, 125(1-2), 305-353.

Smock, P. J., Manning, W. D., \& Gupta S. (1999). The effect of marriage and divorce on women's economic well-being. American Sociological Review, 64(6), 794-812.

Uunk, W. (2004). The economic consequences of divorce for women in the European Union: The impact of welfare state arrangements. European Journal of Population, 20, 251-285. 